\title{
Mainstreaming Agroforestry Policy in Tanzania Legal Framework
}

\author{
Tuli S. Msuya ${ }^{1}$ and Jafari R. Kideghesho ${ }^{2}$ \\ ${ }^{1}$ Tanzania Forestry Research Institute (TAFORI), \\ ${ }^{2}$ Sokoine University of Agriculture (SUA) \\ Tanzania
}

\section{Introduction}

Agroforestry has been defined as a dynamic, ecologically-based natural resources management system that, through the integration of trees in agricultural landscapes, diversifies and sustains production for increased social, economic and environmental benefits (Leakey, 1996; ICRAF, 2007). The system is increasingly considered as a solution for limited available resources and is rapidly emerging as a response to global sustainable development goals due to key role it plays in transforming livelihoods and landscapes (ICRAF, 2008). It provides diverse benefits including inter alia enhancing biodiversity, climate change adaptation and mitigation, food security, and reducing rural poverty by increasing soil fertility and crop yields.

In Tanzania, agroforestry is potentially important for improving the livelihoods of the majority of people, particularly rural communities, through enhanced food security, primary health care (medicinal plants) and the leading source of fuel energy. Essentially, the system has increasingly become a focal entry point for rural development, environmental stewardship including climate change adaptation and mitigation, and ecosystem sustainability through transformation of livelihoods and landscapes (ICRAF, 2008; Boeckmann and Iolster, 2010; Pye-Smith, 2010). Over time Agroforestry research has developed a wide range of practical and robust technologies for different agroecological zones, which have yielded positive and encouraging results in improving food security, livelihoods and environmental resilience (Mbwambo 2004, Boeckmann and Iolster 2010; Pye-Smith 2010). However, human, infrastructure and institutional capacities for agroforestry development are not well developed (Kitalyi et al., 2011).

Widespread adoption of agroforestry technologies requires appropriate policies at national and local levels (Boeckmann \& Iolster 2010). However, there are numerous policy based constraints hindering success of agroforestry in most African countries (Scherr \& Franzel, 2002; Place \& Prudencio, 2006; Boeckmann \& Iolster, 2010) and Tanzania, in particular (Ngatunga and Nshubemuki, 2006; Mmbaga et al., 2007; Otsyina et al., 2010). Among the major constraints are land and tree tenure policies (Lawson et al., 2005; Place and Prodencio, 2006), inadequate legal framework and institutional support and lack of stand alone agroforestry policy besides huge contribution that agroforestry plays in enhancing 
livelihood improvement and poverty alleviation in the country (Otsyina et al., 2010). Options for developing agroforestry are among the major issues of debate in Tanzania. However, they have received very minimal attention in literature. This chapter, therefore, explores how existing national policies and institutional setups facilitate or constrain development of agroforestry policy and the available options for developing such policy.

\section{History of agroforestry in Tanzania and Tanzania legal framework}

Tanzania is home to a variety of traditional agroforestry systems that have been in practice since time immemorial (Otsyina et al., 2010). These agroforestry systems are, therefore, part of the history of the Tanzanian rural landscapes. Some have been documented. Examples include the Chagga home-gardens in north eastern Tanzania (Soini, 2005) and the related Kagera and Mara Regions home-gardens in north western Tanzania (Rugalema et al., 1994), the Usambara traditional based domestication agroforestry systems in north eastern Tanzania (Moshi, 1997; Msuya et al., 2008; Reyes, 2008) and the traditional Wasukuma silvopastoral system called "ngitili" in Western Tanzania (Otsyina et al., 1993; Kamwenda, 2002; Barrow, 2004; Pye-Smith, 2010). One outstanding aspect of these traditional agroforestry systems is the use of multi-layered systems with a mixture of annual and perennial plants, which imitate natural ecosystems.

Agroforestry evolved as a formal scientific discipline in the mid 1970s, but its promotion through research and development activities started in 1980s (Otsyina et al., 2010). The evolution of agroforestry in the last three decades has seen a major shift from emphasis on land productivity at farm level to systems interactions at landscape level (Kitalyi et al., 2011). Agroforestry systems provide both local and global ecosystem services. They play significant roles in realizing the goals of the three UN conventions on desertification, biodiversity and climate change (Figure 1). The three conventions seek to mobilize the science, economics, social and political will in order to bring about sustainability in the use and management of the Earth's natural resources and enhance the life-support systems. Agroforestry is embedded in these conventions due to its ability to transform landscapes and livelihoods by contributing to poverty reduction, improved productivity and achievement of environmental sustainability (ICRAF, 2007).

The potential of agroforestry practice and science to contribute to sustainable development through transforming landscapes and livelihoods is jeopardized by inadequate policy and legal support along with fragmented policy environment. Tanzania has no stand alone policy to guide agroforestry practices and legislation. The only existing document to support agroforestry in the country is the National Agroforestry Strategy of 2004 designed to support scaling up of agroforestry technologies. However, it is silent on other important aspects of agroforestry, especially those related to policy and legal frameworks. For example, this strategy lacks guidance on how policy and related regulations can be formulated.

The National Agroforestry Strategy envisions that four million rural households will adopt and benefit from agroforestry practices by 2025 (NAS, 2004). Its goal by 2020 is for agroforestry technologies to be adopted and contribute appreciably to improving the livelihoods of $60 \%$ of the country's resource-poor households (ibid). The goal of the National Agroforestry Strategy complements the Tanzania's Development Vision 2025 and the National Strategy for Growth and Poverty Reduction (MKUKUTA), which aim at increasing 
household income while conserving the environment. However, formulation of this strategy was not based on reforms of natural resources and agricultural related policies and legislations. It was the Ministry of Agriculture and Food Security (MAFS) and the Ministry of Natural Resources and Tourism (MNRT) that constituted the National Agroforestry Steering Committee (NASCO) in 1993, which in turn formulated the strategy. Although MAFS and MNRT recognize the importance and potential strategy in guiding agroforestry practices and NASCO as the overseer of agroforestry practices in Tanzania, there is little or no structure to institutionalize the Strategy and NASCO into national policy and legal frameworks. Such institutional structures need to be developed, and this can act as important entry point to formulating agroforestry policy.

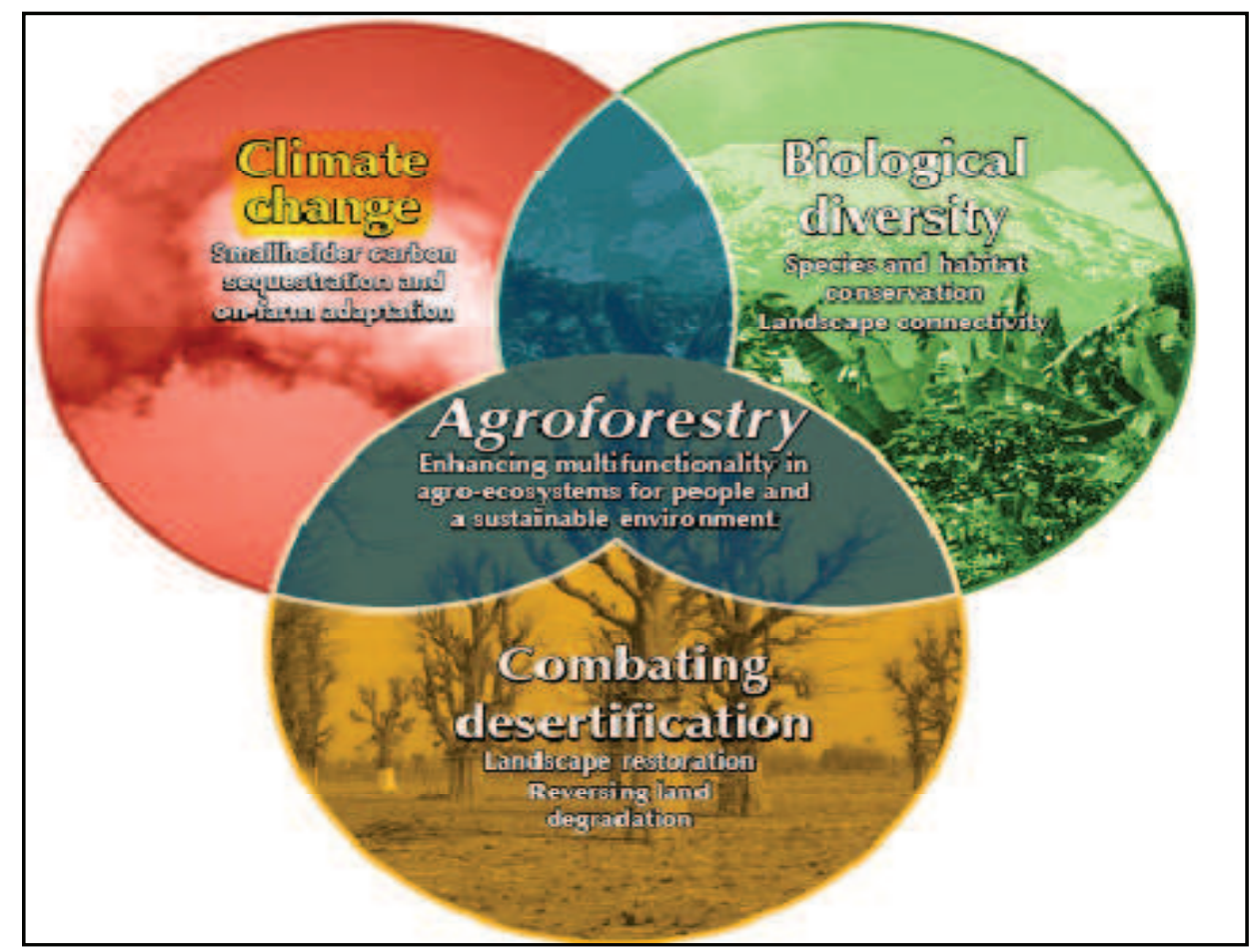

Fig. 1. Agroforestry at the heart of three conventions: combating desertification, biological diversity and climate change (Source: ICRAF, 2007).

Besides the National Agroforestry Strategy, Tanzania has several sectoral policies and legislations. However, they do not systematically address agroforestry issues. The current policies and legislations include:

- $\quad$ The National Forest Policy (1998) and the resultant Forest Act No. 14 of 2002

- The Agricultural and Livestock Policy of Tanzania (1997), Various Legislations

- $\quad$ The National Beekeeping Policy (1998), Beekeeping Act No.15 2002

- The National Fisheries Policy (1998), Act No. 22 of 2003

- The National Environmental Policy (1997), Act No. 20 of 2004 
- $\quad$ The Wildlife Policy (1998) and the Wildlife Conservation Act No. 5 of 2009

- $\quad$ National Water Policy of Tanzania (2002), Act No. 11 of 2009

- National Land Policy (1995), Land Act No. 4 of 1999 and Village Land Act No. 5 of 1999

These new policies and legislations resulted from policy reforms, which started in 1980s. These reforms also underpinned the development of various sectoral programmes and strategies such as National Forest and Beekeeping Programmes, the Agricultural Sector Development Programme and the Water Sector Development Programme. Like the policies and legislations, these regulatory institutions, also lack special provisions for agroforestry practices although they can either enable or constrain agroforestry development. The fact that the Forest Policy of 1998 is currently under review gives a hope that important aspects pertaining to agroforestry practices and management will be accorded adequate and deserved priority.

\section{Agroforestry in different sectoral policy and legal instruments}

Different natural resources policies and legislations (outlined in this section) touch agroforestry issues in various ways.

\subsection{The Forest Policy and legislations}

The policy and legal documents regulating forest resources in Tanzania are the National Forest Policy of 1998, The National Forest Programme (NFP) of 2001 and the Forest Act of 2002. The Forest Policy encourages agroforestry practices by recognizing contribution of trees outside forests in agricultural productivity and forest conservation. However, many of the statements and directives are specifically focusing on forestry and not specifically on agroforestry practices. For example, maintaining ecosystem stability through conservation of forest biodiversity, water catchments and soil fertility is one of the objectives of Forest Policy but it has indirect provisions for agroforestry practices. In fact, there is scholarly consensus that agroforestry practices are potential for ensuring ecosystem sustainability, biodiversity conservation, watershed conservation and soil fertility improvement (Mbwambo 2004; ICRAF, 2008; Otsyina et al., 2010; Pye-Smith 2010). The only direct reference to agroforestry in National Forest Programme is agroforestry definition. As the Forest Policy requires legal framework to translate its objectives to action, the Programme was launched as an instrument to operationalize the Policy, implemented through the Forest Act of 2002.

Both the Forest Policy and the Forest Act provide a strong foundation and legal basis for community managed and privately managed forests implying indirect provision for agroforestry. It is evident that agroforestry is embedded in community-managed forests (Porter-Bolland et al., 2011). In addition, the Forest Policy, National Forest Programme and Forest Act recognize the potential of trees and forests for rural energy sources, provision of various goods (forest products) and services (climate amelioration, carbon sequestration, watershed protection). However, provisions for payment for services offered by trees and forests are not clearly stipulated in existing forest policy and legal documents. In that vein, the 1998 forest policy is currently under review to capture some issues related to payment for ecosystem services under clean development mechanisms (CDM) and reduced emission from deforestation and degradation (REDD) initiatives. These initiatives are opportunities for agroforestry to flourish. 
The Forest Act has some provisions that seem to constrain agroforestry practices. These provisions are related to tree tenure as stipulated in sections 65, 66 and 67 of the Act (URT, 2002). The Act empowers the Minister of Natural Resources to declare any indigenous tree species a "reserved tree" regardless of where they grow, provided it is protected under international agreements due to either importance in biodiversity conservation and genetic resources value or the risk/vulnerability to extinction (URT, 2002). Under these laws, reserved trees or parts of these trees are protected from cutting or removal without permission ( $\mathrm{ibid}$ ). On one hand, these provisions can limit investment in agroforestry (tree planting and/or retention), but on the other hand, they can encourage some useful interventions such as domestication and conservation of traditional natural forests in order to capture benefits from CBM and REDD funds.

\subsection{The Agricultural Policy and legislations}

The agricultural sector in Tanzania is governed by the National Agricultural and Livestock Policy of 1997, the Agricultural Sector Development Strategy (ASDS) of 2001, the Agricultural Sector Development Programme (ASDP) of 2006, and various legislations. The National Agricultural and Livestock Policy of 1997 recognizes the need to utilize the national scientific and technological capacity in the promotion of agricultural production and productivity. The policy underscores the need to harness both science and technology and indigenous knowledge in addressing constraints to agricultural production. While the policy puts more emphasis on technology generation, its emphasis on agroforestry technologies is minimal.

The Agricultural Sector Development Strategy was formulated as an instrument to strategize the Agricultural and Livestock Policy of 1997. The strategy envisages that by 2025, agriculture becomes modernized, commercial, highly productive and profitable, and utilizes natural resources in a sustainable manner. This can be achieved by setting up the favorable environment to raise productivity, promotion of public-private partnerships, promotion of private sector production, processing, storage and input supply and decentralization of agricultural planning activities to district level. As the Strategy is the driving force for modernization of agriculture, it puts more emphasis on demand driven and market-led technology development and adaptation, and the role of public sector to be regulatory and supportive to private sector functions. To operationalize the strategy, the Agricultural Sector Development Programme was formulated in 2006. On the other hand, there are a number of legislations governing crops, livestock, pesticides, inputs, market and other related matters pertaining to agricultural and livestock production in agriculture and livestock sectors.

Agriculture and livestock are important components of agroforestry, but agroforestry issues have been hitherto neglected in agricultural development policy and legislation documents. Many of the issues addressed in agriculture and livestock policy and legal documents are not specific to agroforestry technology development and uptake. Mainstreaming agroforestry policy, thus, is essential to bring it to an even playing field.

\subsection{The National Environmental Policy and legislations}

The policy reform in environmental sector has resulted into the National Environmental Policy (NEP) of 1997 followed by the National Environmental Management Act (NEMA) of 
2004, the Environmental Impact Assessment and Audit Regulations of 2005, and the Environmental Management and Soil Quality Standards Regulations of 2007. These policy and legal instruments provide a framework for environmental protection by different sectors in view of ensuring environmental integrity and sustainability. The Environmental Policy and legal documents underscore the need for agricultural sector to contribute to food security and rural poverty alleviation through the promotion of production systems, technologies and practices that are environmentally friendly, with emphasis on strengthening of environmentally sound use. Since agroforestry technologies and practices are environmentally friendly, one would have expected the Environmental Policy to carry provisions on agroforestry, but this is not the case.

\subsection{The Land Policy, Land Act and Village Land Act}

The Land Policy of 1995 aims at promoting a secure land tenure system. It encourages the optimal use of land resources. The policy states the need for broad-based social and economic development without upsetting or endangering the ecological balance of the environment. The legal basis for land tenure in Tanzania is derived from two basic laws: the Land Act of 1999 and the Village Land Act of 1999. The Acts hold a statement that "all land in Tanzania is public land, which the President holds in trust for all citizens". The President delegates the power to designate, adjudicate, and modify land tenure status to the Commissioner of Land. District councils and village councils play an important role in managing land at the local level. The two legal instruments have the overall objective of formalizing and legalizing what is traditional and customary land tenure systems. In that regards, the Village Land Act has provision for women to own land. This encourages investment in agroforestry for both men and women.

\subsection{Water Policy and legislations}

Governing policy and legislation instruments in water sector are the National Water Policy of 2002, the Water Sector Development Programme of 2006 and the Water Resources Management Act of 2009. These policy and legal instruments recognize water as a fundamental resource for life and various socio-economic development activities and hence the need to conserve water sources. Though not recognized in water policy and legal instruments, agroforestry plays crucial role in the conservation of water sources and improving water quality through conserving the soils.

\subsection{Fisheries Policy and legislations}

The major focus of the Fisheries Policy and legal instruments is on the promotion of sustainable exploitation, utilization and marketing of fish resources to realize the intended national socio-economic objectives and achieve effective protection of the aquatic environment for sustainable development. The policy has no direct provisions for agroforestry practices although fish ponds are also found in many farming systems and once the fish feeds on tree biomass the system becomes an agroforestry practice. For example, Leucaena leucocephala from alley cropping is known to provide nutritive feed to fish (Sotolu \& Faturoti, 2008). The technology involving interaction of trees with fish is generally known as silvopastoral. 


\subsection{Beekeeping Policy and legislations}

The Beekeeping Policy and Act envisage that beekeeping plays a major role in socioeconomic development and environmental conservation in Tanzania. The system of agroforestry involving beekeeping is called apiculture. Though not recognized directly in beekeeping policy and legal documents, apiculture is considered to be an agroforestry technology directly once the hives are set up in the trees, or indirectly when the bees gather nectar from tree flowers (Okia et al., 2009).

\subsection{Wildlife Policy and legislations}

The 1998 Wildlife Policy of Tanzania (revised in 2007) and the Wildlife Conservation Act of 2009, have two important provisions: one encouraging and another one discouraging agroforestry development. On the one hand, the policy and its associated Act recognize the role of trees as habitat and forage for wild animals, thereby encouraging the practice through tree planting and/or retention on farms. On the other hand, the Policy and Act call for protection of wild animals even if they occur on farmlands. This implies that, even in cases where the wild animals raid and destroy crops, farmers are not allowed to kill them. Their action is limited to informing the Game Officers. This can discourage agroforestry as farmers might hesitate to plant trees on their farms because trees provide suitable habitats for wild animals and, therefore, subject agricultural crops to damage.

\section{Factors contributing to lack of National Agroforestry Policy}

This section highlights the possible factors contributing to lack of Agroforestry Policy in Tanzania's policy and legal framework.

\subsection{Scattered/lack of adequate information}

Relevant information on agroforestry issues is inadequate and scattered. This, therefore, undermines efforts for formulation of policy. Some important information on agroforestry practices is localized in some areas and not accessible to planners and policy makers. This is compounded by inadequate coordination of agroforestry research and development in Tanzania (Otsyina et al., 2010; Kitalyi et al., 2011).

\subsection{Existence of many sectoral policies and legal instruments}

Various policies, legal instruments and traditional practices guide agroforestry practices due to their cross-sectoral nature. Several natural resources related policies and legal instruments currently govern Agroforestry practices. There is lack of policy space for coordinating the range of policies, laws and regulations that have impacts on agroforestry. This amplifies potentials for having conflicting and overlapping policy and legal frameworks. Such cases involve examples where agricultural, environmental and forest policies promote tree planting, but the Forest Act protects species and restricts felling; and where agriculture policy promotes small scale stream fed irrigation while the Environmental Act promotes riverbed protection and cropping bans. This situation is attributed to poor institutional coordination. 


\subsection{Lack of agroforestry sectoral affiliation}

There is no single sector in Tanzania where agroforestry is affiliated. As a result different institutions and organizations are undertaking and/or promoting agroforestry activities with little or no coordination. This makes agroforestry information scattered in various sectors.

\subsection{Lack of recognition and integration of NASCO in government structure and plans}

The coordination of agroforestry research and development activities is vested under the National Agroforestry Steering Committee (NASCO) through its current Secretariat, the Tanzania Forestry Research Institute (TAFORI). However, NASCO is not institutionalized at any level of government structure. As a result, its activities are not properly recognized at national and district levels and, therefore, are not fully supported by the government.

\subsection{Lack of financial resources}

Since agroforestry has no sectoral affiliation, it scarcely be allocated funds during budgeting session. It is not stipulated in the National Agroforestry Strategy (NAS) how the funds to cater for agroforestry activities can be sourced. As a result, NASCO becomes financially strapped and fail to conduct its scheduled meetings.

\subsection{Weak integration of NAS in National Legal Framework}

Notwithstanding the role and potential of NAS in contributing to the Tanzania Development Vision 2025 and the Poverty Reduction Strategy, NAS has not been institutionalized in any of the natural resources related policies and legal instruments. The NAS is seen as a stand-alone document, only supported by the World Agroforestry Strategy 2008 - 2015 (ICRAF, 2008).

\subsection{Lack of awareness on the importance of Agroforestry Policy}

There is inadequate effort devoted to awareness creation on the importance of Agroforestry Policy in Tanzania. The smallholder farmers in Tanzania are the major recipients of agroforestry knowledge and technologies. Unfortunately, majority of farmers and other stakeholders involved in different agroforestry activities have not been sensitized enough on the importance of agroforestry policy in fostering agroforestry development.

\section{Need for National Agroforestry Policy in Tanzania}

In Tanzania, management challenges are increasingly justifying the need for agroforestry to have its own policy. Some advocacy strategies that can contribute to the formulation of the National Agroforestry Policy include:

- Policy supporting analyses and best practices at different levels

- Establishment of policy dialogue at the national and local levels on agroforestry issues. This should include civil society, private sector, sectoral departments and senior policymakers 
- Capitalizing on the opportunities provided under NAS to influence policy on the need of mainstreaming agroforestry in the policy agenda

- Capitalizing on NASCO as an overseer of agroforestry matters to stir agroforestry policy development

- Involvement of Local Government and its machinery is an essential entry point as a lot of decisions evolve from this important sector

- Institutionalize NAS as part of the official programme in agricultural and natural resources sectors

- Institutionalize and support formation of "science-policy forum" where updates on agroforestry research results and opportunities are presented to policy makers to stir agroforestry policy debate.

\section{Key players in Agroforestry Policy development include}

- Vice President Office (VPO), Division of Environment

- Local government authorities

- Ministries and their respective agencies

- Development partners and other International Organizations

- Research and academic institutions

- NGOs and other civil society organizations

- Local communities

- Private companies

- World Agroforestry Centre (ICRAF)

\section{Some issues that need to be addressed in the National Agroforestry Policy include}

- How does agroforestry meet the key social values

- Which costs can agroforestry interventions reduce

- How could agroforestry systems be tailored to respond to local conditions (institutional, cultural, economic, environmental)

- How could agroforestry interventions/practices assist various stakeholders to realize their interests

- Governance and tenure (land and tree tenure): Rights to land and trees for smallholder farmers and rural communities, and women's rights and roles in agroforestry.

- Improved marketing for agroforestry products: Here we consider issues of marketing information; agroforestry products value chains and development of environmental services reward systems for smallholder agroforesters

- Policy coordination: Mechanisms for planning and reviewing agricultural and natural resources policies through agroforestry lens, given that agroforestry is not the domain of a single sector. Space for agroforestry in various inter-sectoral panels/committees such as on climate change and REDD

- Harmonization of different natural resources policy and legal instruments: Since agroforestry means integration of trees on agricultural land to contribute to livelihood strategies and environmental sustainability, all contradictions and conflicting interests and mandates in different policy and legal instruments which touch agroforestry need to be harmonized. 


\section{Process for enacting Agroforestry Policy}

- Stakeholders consultations

- Developing agroforestry draft policy and its implementation plan

- Stakeholders draft policy verifications

- Process approval by Cabinet Secretariat

- Discussion and endorsement of the draft policy at the Inter-Ministerial Committee

- Approval by the Full Cabinet

- $\quad$ Signed by the President

Notwithstanding existence of many uncoordinated policy and legal instruments governing agroforestry, there is still a potential to enact specific policy for agroforestry based on the procedure outlined above. Some African countries have already developed such policy as exemplified by the Agroforestry Policy of Ghana (MOFA, 1986).

\section{Conclusions}

Agroforestry systems have huge potential to contribute to three pillars of sustainable development: ecological sustainability, economic sustainability and social sustainability through positive transformation of landscapes and the livelihoods of rural Tanzanians. However, the potential of the systems is constrained by lack of supportive regulatory framework and poor coordination of the practices triggered by lack of stand alone agroforestry policy. Since, many agricultural and natural resources related policies and legal instruments touch issues related to agroforestry; it is imperative that these policies are harmonized along with carrying out lobbying and advocacy geared towards the formulation of Agroforestry Policy.

\section{Recommendations}

The following are the recommendations aimed at facilitating the process of developing Agroforestry Policy in Tanzania:

- Reinforce NASCO to make it more inter-sectoral

- Create public awareness of the importance of Agroforestry Policy

- Set aside agroforestry funds at different levels

- Integrate indigenous and modern technologies in Agroforestry Policy

- Institutionalize NASCO in the government structure and plans, as an overseer of agroforestry activities

- Institutionalize NAS in Tanzania's legal framework

- Forest and Agricultural sectors should take the lead to stir up a process for Agroforestry Policy Development. Therefore, they need to establish effective partnership and collaboration rather than working in isolation.

- $\quad$ Enact National Agroforestry Policy

- Consider redefining agroforestry in the Tanzanian context because the country has already proposed a new forest definition. A Forest, in Tanzania, is defined as an area of land with at least 0.05 hectares, with a minimum tree crown cover of $10 \%$ or with existing tree species planted or natural having the potential of attaining more than $10 \%$ crown cover, and with trees which have the potential or have reached a minimum height of 2.0 meters at maturity in situ (MNRT, 2011).

- Ensure that at least 50\% of Agroforestry plot is kept under crop or pasture production. 


\section{References}

Barrow, E. 2004. Ngitili for Everything: Woodland Restoration in Shinyanga, Tanzania.

Boeckmann, S.P. \& Iolster. 2010. Agroforestry in Africa: Exploring the Lack of Widespread Implementation and the Potential for Expansion. Available from http:/ / www.rmportal.net/library. Accessed on 12 April, 2011

Brochure. Ministry of Natural Resources and Tourism and the Tanzania and Eastern Africa Regional Office of IUCN - The World Conservation Union. Dar es Salaam, Tanzania.

ICRAF (World Agroforestry Centre). 2007. Tackling Global Challenges through Agroforestry Annual Report for 2006. World Agroforestry Centre (ICRAF). Nairobi, Kenya. 64pp.

ICRAF (World Agroforestry Centre). 2008. Transforming lives and landscapes. ICRAF Strategy 2008-2015. World Agroforestry Centre, Nairobi, Kenya. 48pp.

IUFRO. 2005. Multilingual Pocket Glossary of Forest Terms and Definitions. International Union of Forest Research Organizations, Vienna, Austria. 96 pp.

Kamwenda, G.J. 2002. Ngitili agrosilvipastoral systems in the United Republic of Tanzania. Unasylva 53: 46-50.

Kitalyi, A.; Nyadzi, G.; Lutkamu, M.; Swai, R.; Gama, B. 2011. New climate, new agriculture: how Agroforestry contributes to meeting the challenges of Agricultural development in Tanzania. Tanzanian Journal of Agricultural Sciences, 10 (1): 1 - 7.

Lawson, G.; Dupraz, C.; Liagre, F.; Moreno, G.; Piero Paris, P. and Papanastasis, V. 2005. Options for Agroforestry Policy in the European Union. Silvoarable Agroforestry For Europe (SAFE). Available online at:

http://www 1.montpellier.inra.fr/safe/english/results/final-report/D9-3.pdf, Accessed August, 12, 2011.

Leakey, R.R.B. 1996. Definition of agroforestry revisited. Agroforestry Today 8: 5-7.

Mbwambo, J.S. and E.E. Chingonikaya. 2004. Adoption of agroforestry practices and their contribution to poverty reduction among rural households: A case study of to maize and woody biomass yields and income in Musoma Rural District, Mara Region Tanzania.

Mmbaga, T. E., C. J. Lyamchai, H.Mansoor, J.Wickama 2007. Practical Approaches for Effective by-laws in Lushoto District. AHI Reports, Lushoto Benchmark. MNRT 2011. Proposed National Definition of Forest for Tanzania. Ministry of Natural Resources and Tourism. Dar es Salaam, Tanzania.

MOFA (1986). The National Agroforestry Policy. Ministry of Food and Agriculture Accra, Ghana

Moshi ERF. 1997. Inventory of indigenous agroforestry systems in practice in the West Usambara Mountains. [unpublished MSc thesis]. [Morogoro (Tanzania)]: Sokoine University ofAgriculture.

Msuya TS, Mndolwa MA, Kapinga C. 2008. Domestication: an indigenous method in conserving plant diversity on farmlands in West Usambara Mountains, Tanzania. African Journal of Ecology, 46(1):74-78.

NASCO (National Agroforestry Steering Committee). 2004. Popular Version of National Agroforestry Strategy. NASCO Secretariat, Tanzania Forestry Research Institute, Morogoro, Tanzania.

Ngatunga, E.L. and Nshubemuki, L. (2006). Need for policy on agroforestry research and development in Tanzania. In: S.A.O. Chamshama et al. (Eds). Partnerships and 
Linkages for Greater Impact in Agroforestry and Environmental Awareness. Proceedings of the Second National Agroforestry and Environment Workshop held in Mbeya 14 - 17 March 2006. Pp 224-229.

Okia, C.A.; Agea, J.G.; Sekatuba, J.; Ongodi, G.; Katumba, B.; Opolot, V.I and Mutabazi, H. 2009. Candidate Agroforestry Technologies and Practices for Uganda. Agricultural Journal, 4(5): 208-215.

Otsyina, R., S. Minae, and D. Asenga. 1993. The Potential of Ngitili as a Traditional Agroforestry System among the Sukuma of Tanzania. Nairobi, Kenya: World Agroforestry Centre (ICRAF).

Otsyina, R.; Chamshama, S.A.O.; Gama. B.; Kitalyi, A.; Mpanda, M.; Lutkam, M.; Iddi, S. and Mhando, L. 2010. Role of Agroforestry in Improving Livelihoods of Rural Communities and Environmental Sustainability in Tanzania. A Position Paper. National Agroforestry Steering Committee, Morogoro, Tanzania. 19 pp.

Place, F., Prudencio, Y-C., 2006. "Policies for improved Land Management in smallholder Agriculture: The Role of Research in Agroforestry and Natural Resource Management: World Agroforestry into the Future, Garrity, D., Okono, A., Grayson M., Parrot, S., Eds. World Agroforestry Center, 2006. P. 71-78.

Porter-Bolland, L.; Ellis, E.A.; Guariguata, M.R.; Ruiz-Mallén, I.; Negrete-Yankelevich, S.; Reyes-García, V. 2011. Community managed forests and forest protected areas: An assessment of their conservation effectiveness across the tropics. Article in press. Forest Ecology and Management.

Pye-Smith C. 2010. A Rural Revival in Tanzania: How agroforestry is helping farmers to restore the woodlands in Shinyanga Region. ICRAF Trees for Change no. 7. Nairobi: World Agroforestry Centre. $48 \mathrm{pp}$.

Reyes, T. 2008. Agroforestry systems for sustainable livelihoods and improved land management in the East Usambara Mountains, Tanzania. PhD Thesis. University of Helsinki, Finland. 166 pp.

Rugalema G. H., A. Okting'ati and F. H. Johnsen. 1994. The homegarden agroforestry system of Bukoba district, North-Western Tanzania. Farming system analysis. Agroforestry Systems 26: 53-64, 1994. 91994 Kluwer Academic Publishers, The Netherlands.

Scherr, S.J. and Franzel, S. 2002. Promoting New Agroforestry Technology: Policy Lessons from on Farm Research. In: Franzel, S. and Scherr, S.J. (Eds). Trees in the Farm: Assessing the Adoption Potential of Agroforestry Practices in Africa. Wallingford, Oxon, UK, New York. Pp 145 -168.

Soini, E. 2005. Changing livelihoods on the slopes of Mt. Kilimanjaro, Tanzania: Challenges and opportunities in the Chagga homegarden system. Agrofeorestry Systems Journal, 64 (2): $157-167$

Sotolu, A.O. and Faturoti, E.O. 2008. Digestibility and nutritional values of Differently Processed Leucaena leucocephala (Lam. de Wit) Seed Meals in the Diet of African Catfish (Clarias gariepinus). Middle-East Journal of Scientific Research 3 (4): 190-199.

URT (United Republic of Tanzania). 1998. National Forest Policy. Government Printer, Dar es Salaam, Tanzania. 59pp.

URT (United Republic of Tanzania). 2002. Forest Act No. 14 of 2002. Government Printer, Dar es Salaam, Tanzania. 93pp. 
AGROFORESTRY FOR

BIODIVERSITY AND

ECOSYSTEM SERVICES

SCIENCE ANO PRACTICE

Ededa by Murts Leckion Kionga

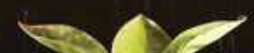

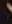

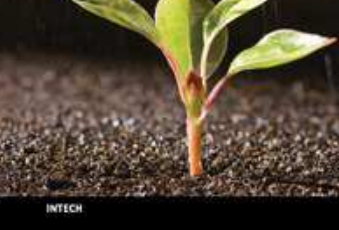

\section{Agroforestry for Biodiversity and Ecosystem Services - Science and Practice}

Edited by Dr. Martin Kaonga

ISBN 978-953-51-0493-3

Hard cover, 164 pages

Publisher InTech

Published online 04, April, 2012

Published in print edition April, 2012

Agroforestry has great potential for reducing deforestation and forest degradation, providing rural livelihoods and habitats for species outside formally protected land, and alleviating resource-use pressure on conservation areas. However, widespread adoption of agroforestry innovations is still constrained by a myriad of factors including design features of candidate agroforestry innovations, perceived needs, policies, availability and distribution of factors of production, and perception of risks. Understanding the science, and factors that regulate the adoption, of agroforestry and how they impact the implementation of agroforestry is vitally important. Agroforestry for Biodiversity and Ecosystem Services: Science and Practice examines design features and management practices of some agroforestry practices and their impact on biodiversity and the ecosystem services it delivers. It also identifies policy issues for facilitating adoption of desirable agroforestry practices and gradual diminution of undesirable policies.

\section{How to reference}

In order to correctly reference this scholarly work, feel free to copy and paste the following:

Tuli S. Msuya and Jafari R. Kideghesho (2012). Mainstreaming Agroforestry Policy in Tanzania Legal Framework, Agroforestry for Biodiversity and Ecosystem Services - Science and Practice, Dr. Martin Kaonga (Ed.), ISBN: 978-953-51-0493-3, InTech, Available from: http://www.intechopen.com/books/agroforestry-forbiodiversity-and-ecosystem-services-science-and-practice/mainstreaming-agroforestry-policy-in-tanzanialegal-framework

\section{INTECH}

open science | open minds

\section{InTech Europe}

University Campus STeP Ri

Slavka Krautzeka 83/A

51000 Rijeka, Croatia

Phone: +385 (51) 770447

Fax: +385 (51) 686166

www.intechopen.com

\section{InTech China}

Unit 405, Office Block, Hotel Equatorial Shanghai

No.65, Yan An Road (West), Shanghai, 200040, China

中国上海市延安西路65号上海国际贵都大饭店办公楼 405 单元

Phone: +86-21-62489820

Fax: $+86-21-62489821$ 
(C) 2012 The Author(s). Licensee IntechOpen. This is an open access article distributed under the terms of the Creative Commons Attribution 3.0 License, which permits unrestricted use, distribution, and reproduction in any medium, provided the original work is properly cited. 